\title{
GROWTH, YIELDING AND HEALTHINESS OF GRAPEVINE CULTIVARS 'SOLARIS' AND 'REGENT' IN RESPONSE TO FERTILIZERS AND BIOSTIMULANTS
}

\author{
Jerzy LISEK*, Lidia SAS-PASZT, Edyta DERKOWSKA, Tomasz MROWICKI, \\ Michał PRZYBYŁ, Mateusz FRĄC \\ Research Institute of Horticulture \\ Konstytucji 3 Maja 1/3, 96-100 Skierniewice, Poland
}

Received: July 2016; Accepted: October 2016

\begin{abstract}
In the years 2008-2015, field experiments were conducted on the vines of cultivars 'Solaris' and 'Regent' grafted on SO4 rootstock. The following treatments: 1. control (untreated), 2. NPK (mineral fertilization $70 \mathrm{~kg} \mathrm{~N} \cdot \mathrm{ha}^{-1} ; 40 \mathrm{~kg} \mathrm{P} \cdot \mathrm{ha}^{-1} ; 120 \mathrm{~kg} \mathrm{~K} \cdot \mathrm{ha}^{-1}$ ), 3. mycorrhizal substrate (AMF - Arbuscular Mycorrhizal Fungi), 4. NPK + AMF, 5. manure (before planting), 6. NPK + manure (before planting), 7. Bioilsa, 8. NPK + Bioilsa, 9. BF-Ecomix, 10. NPK + BF-Ecomix, 11. Ausma and 12. NPK + Ausma were applied to evaluate the usefulness of biostimulants and mineral and organic fertilizers in organic grapevine production in "cool climate" conditions of Poland. The tests did not show a definite positive effect of the biostimulants and organic fertilizers on growth, yielding and healthiness of the cultivars 'Solaris' and 'Regent'. There were no substantial differences in total marketable yield in the years 2009 to 2015 between control and other treatments. Grapevines planted in soil rich in minerals grew and yielded well despite no mineral fertilization for a number of years. In 2014, when the air humidity was high during vegetation, intensive rotting of the berries of cultivar 'Solaris', caused by Botrytis cinerea, was observed on plants fertilized with NPK.
\end{abstract}

Key words: Vitis sp. L., field trials, fertilization, bioproducts

\section{INTRODUCTION}

Grapevine is one of the most important fruit crops in the world. Majority of fruit picked from the cultivation area of 7.6 million ha is processed into wine, and the annual global production of this wine amounts to 265 million hectoliters (OIV - International Organization of Vine and Wine 2013). In Poland, the total vineyard area is estimated at $600-700$ ha, but in the past decade, it has been systematically expanding every year. The cultivars 'Solaris' and 'Regent', commonly cultivated in Poland, were bred in Germany and are classified either as Vitis vinifera cultivars (Vitis International Variety Catalogue 2016) or as inter-intraspecific hybrids (Theocharis et al. 2010). Both 'Regent' and 'Solaris' are characterized by resistance to frost higher than most of the original Vitis vinifera cultivars and low sensitivity to fungal diseases (Lisek 2010; Lott et al. 2010).
The roots of grapevine (Vitis vinifera and other Vitis species) in field conditions are commonly colonized by arbuscular mycorrhizal fungi (Schreiner 2003; Schreiner \& Mihara 2009; Balestrini et al. 2010). The presence of mycorrhizal fungi is vital for the normal growth and development of grapevine (Biricolti et al. 1997; Linderman \& Davis 2001). Improved growth of grapevine of various cultivars, which results from mycorrhization, is closely related to the uptake of the following minerals from soil: phosphorus (Schreiner 2007; Ozdemir et al. 2010), nitrogen (Hawkins et al. 2000; Mäder et al. 2000; Hodge et al. 2001; Patrick et al. 2004), iron, copper and zinc (Turan \& Köse 2004; Ozdemir et al. 2010). AM fungi increase grapevine's tolerance to drought (Nikolaou et al. 2003; Schreiner 2003; Schreiner \& Linderman 2005; Schreiner et al. 2007, Donkó et al. 2014). AM fungus Glomus versiforme activates 
grapevine's (Vitis amurensis Rupr.) defense mechanism against parasitic nematodes Meloidogyne incognita (Li et al. 2006). Inoculation of grapevine roots with the Glomus iranicum mycorrhizal fungi reduces the effects of water stress, improves photosynthesis and yield, and speeds up the ripening time of table grapes cv. 'Crimson' (Nicolás et al. 2015). The soil $\mathrm{pH}$ below 5.5 reduces the colonization of roots by the arbuscular mycorrhizal fungi - AMF (Schreiner \& Linderman 2005), as does the soil cultivation in the interrows (Schreiner 2005). Shallow soil cultivation accompanied by weed control in the grapevine row does not limit the colonization of grapevine roots by the arbuscular mycorrhizal fungi (Baumgartner et al. 2005).

Between biostimulants, applied successfully in the cultivation of grapevine, the following were reported: chitosan (Górnik et al. 2008), nitrophenols (Asahi SL) (Górnik et al. 2007) and marine-plant extracts (Colapietra \& Alexander 2006; Norrie \& Keathley 2006; Kok et al. 2010; Mohamed et al. 2013; Popescu \& Popescu 2014; Stroe \& Budescu 2013).

The aim of the application of biostimulants is also the reduction of sensitivity of grapevine ( $V . v i$ nifera $\mathrm{L}$.) to fungal and phytoplasmatic diseases. It was successful in using different preparations containing extracts of algae (Aziz et al. 2003; Žežlina et al. 2010; Le Mire et al. 2016). Glutathione + oligosaccharides and benzothiadiazole applied as foliar treatment, inhibit the development of Phytoplasma (Bois noir) on grapevine (Romanazzi et al. 2009). Biofertiliser improved both vegetative growth, yield and fruit quality of two seedless grapevine cultivars (El-Sabagh et al. 2011a, b).

The aim of the study was to assess the effect of biostimulants, mineral and organic fertilizers on growth, yield and health status of plants of the grapevine cultivars 'Solaris' and 'Regent' in a multi-year field experiment and also, to evaluate their usefulness in organic production in "cool climate" conditions.

\section{MATERIALS AND METHODS}

The field experiment was conducted in the Experimental Orchard of the Research Institute of Horticulture in Skierniewice, central Poland (latitude $51^{\circ} 57^{\prime} \mathrm{N}$, longitude $20^{\circ} 08^{\prime} \mathrm{E}$ ), located on a medium quality pseudo-podsolic soil (graded Class IV), slightly acidic ( $\mathrm{pH}$ 6.0), containing (as \% DW): $2.37 \mathrm{~N}, 0.15 \mathrm{P}, 1.35 \mathrm{~K}, 0.22 \mathrm{Mg}, 1.64 \mathrm{Ca}$; microelements $\left(\mathrm{mg} \mathrm{kg}^{-1}\right): 3.2 \mathrm{~B}, 13.5 \mathrm{Cu}, 1084 \mathrm{Fe}, 96.6 \mathrm{Mn}$ and $11.8 \mathrm{Zn}$, and $1.3 \%$ of organic matter. The average sum of active temperatures (SAT) - medium daily temperature higher than $10^{\circ} \mathrm{C}-$ in Skierniewice in the years 2008-2015 amounted to $2627^{\circ} \mathrm{C}$. SAT varied from $2422^{\circ} \mathrm{C}$ in 2010 to $2851{ }^{\circ} \mathrm{C}$ in 2014 . The average annual total precipitation amounted to $500 \mathrm{~mm}$ and ranged from $316 \mathrm{~mm}$ in 2015 to $680 \mathrm{~mm}$ in 2010. In the course of the study, the following minimum winter temperatures below $-20.0^{\circ} \mathrm{C}$ were noted: $-23.0^{\circ} \mathrm{C}(6.01 .2009) ;-28.1^{\circ} \mathrm{C}$ (26.01.2010); $\quad-22.3{ }^{\circ} \mathrm{C} \quad(22.02 .2011) ; \quad-23.3^{\circ} \mathrm{C}$ (04.02.2012); $-21.4^{\circ} \mathrm{C}(24.03 .2013)$. Plants of two "PIWI" (abbreviation from German "Pilzwiderstandsfähig" - fungus resistant) grapevine cultivars 'Solaris' (with yellow-green berry skin) and 'Regent' (blue-black), grafted onto rootstock $\mathrm{SO} 4$ (V. berlandieri $\mathrm{x} V$. riparia), were planted in the spring of 2008 and trained as a double Guyot with $10-14$ bud canes and low $(0.3-0.4 \mathrm{~m})$ trunk. The experiment was conducted in randomized complete blocks with 4 replications and 4 plants in each (16 vines per treatment). The spacing between plants in the row was $1.25 \mathrm{~m}$, in the inter-rows $2.7 \mathrm{~m}$, and the isolation strip between the plots was $1 \mathrm{~m}$ wide. From the time of planting until 2012, in the months between May and August, the soil in the inter-rows was cultivated with a rototiller every 4-6 weeks. From 2013, the inter-rows were maintained under spontaneous vegetation, mowed several times during the season. Weeds under the vine canopies were removed by hand. During the growing season, $1-2$ treatments were performed with pesticides containing mancozeb and sulphur. The experimental plots were not irrigated throughout in the entire study period.

In the years 2008-2015, the experimental combinations, arranged in a system of randomized blocks, were as follows:

1. Control combination - untreated plants.

2. Mineral NPK fertilization (at the doses of $70 \mathrm{~kg}$ $\mathrm{N} ; 40 \mathrm{~kg} \mathrm{P} ; 120 \mathrm{~kg} \mathrm{~K}$ were used per hectare. In spring, $70 \mathrm{~g}$ ammonium nitrate, $77.5 \mathrm{~g}$ granular triple superphosphate and $97.5 \mathrm{~g}$ potassium sulfate were used per plant. 
3. Mycorrhizal substrate (produced by MYKOFLOR, Poland), containing $1000000 \mathrm{~g}^{-1}$ propagules of arbuscular mycorrhizal fungi (Glomus intraradices, G. mosseae, G. etunicatum) was used in the area of the root system at $200 \mathrm{~g}$ per vine, at the beginning of the experiment; however, it was added to the soil in the spring of each year (AMF).

4. Mineral NPK fertilization (applied as in the treatment 2) + AMF (as applied in the treatment 3) .

5. Fertigo granulated manure (product of the Dutch company Ferm-O-Feed) was applied at the rate of $25 \mathrm{dm}^{3}$ per plot, in the year of vines planting (plot surface area $5 \mathrm{~m}^{2}$ ).

6. Mineral NPK fertilization (as in the treatment 2) + Fertigo manure (as in the treatment 5).

7. Bioilsa (commercial product in the form of granules applied to the soil, produced by ILSA Group Arzignano, Vicenza, Italy, containing organic nitrogen $\mathrm{N}-12.5 \%$, including organic nitrogen soluble in water $-5 \%$, organic carbon of biological origin $\mathrm{C}-42 \%$, including extracted organic carbon - 95\%) was applied in an amount of $24 \mathrm{~g}$ per plant to the soil in the spring every year.

8. Mineral NPK fertilization (as in the treatment 2)

+ Bioilsa (as in the treatment 7).

9. BF-Ecomix (commercial product of plant origin in the form of granules applied to the soil; AgroBio Products, Wageningen, NL) was applied at the rate of $100 \mathrm{~g}$ per plant to the soil every year in the spring.

10. Mineral NPK fertilization (as in the treatment 2) + BF-Ecomix (as in the treatment 9).

11. Ausma (plant product derived from steam-distilled pine needles, applied in a liquid form to the leaves; produced by Biolat, Lithuania) was used every year as a foliar application at 9, 6, and 3 weeks before harvest at the concentration of $0.1 \%$.

12. Mineral NPK fertilization (as in the treatment 2) + Ausma (as in the treatment 11).

\section{Plant growth assessment}

Plant growth was assessed after each summer pruning, by weighing the fresh herbaceous shoots removed from the end of July until the end of August. Main branches were pruned higher than the $8^{\text {th }}$ to $10^{\text {th }}$ leaf, above the highest growing cluster on the shoot. The side shoots were pruned 2 or 3 times, above the $1^{\text {st }}$ or $2^{\text {nd }}$ leaf from the base. The removed ligneous (mature) shoots were weighed after winters, during pruning which was carried out from the end of February until mid-March.

\section{Yield assessment}

The following features were assessed: time of overall ripening (typical color of berry skin, firmness of flesh and brown seeds), marketable yield, weight of clusters and berries, soluble solids content of fruit and susceptibility of vines to fungal diseases. Mature grapes were harvested separately from each evaluated vine. All clusters were counted. 100 berries collected from 3 typical bunches on each vine were weighed. Soluble solids content of a grape juice was determined by the index of refraction and was measured using a digital hand-held "pocket" refractometer PAL-1 (ATAGO Co. Ltd, Tokyo, Japan). It was measured on 3 randomly chosen clusters from each bush. Juice was squeezed from 15 berries from each cluster (berries were gathered equally from the base, the middle and the top of the bunch). Statistic calculations were conducted with the use of arithmetical averages from the refractometer readings.

\section{Assessment of damage caused by fungal diseases}

An assessment of damage caused by downy mildew (Plasmopara viticola) and powdery mildew (Erysiphe necator) was conducted directly before harvest on each plot in five-grade scale, according to the following criteria: 1 - lack of damage, 2 - less than $20 \%$ of leaves and young shoots infested by both type of mildew, $3-21-50 \%$ of infested leaves and young shoots, 4 - heavily infested leaves and young shoots, together with slight (up to 10\%) infestation of berries, and 5 - heavily infested leaves, shoots (more than 50\%) and berries (more than $10 \%)$. Susceptibility to decay caused by grey mold (Botrytis cinerea) was assessed during harvest, in six-grade scale: 1 - lack of damage, 2 - damage up to $3 \%, 3-4-10 \%, 4-11-25 \%, 5-26-60 \%$, and 6 - more than $60 \%$ of fruit infested. In 2014, due to strong infestation of fruit of the cultivar 'Solaris' with grey mold, the weight of rotten fruit was determined. The occurrence of excoriose (Phomopsis viticola Sacc.), which causes death of wood and buds, was assessed in the period of pruning (February- 
March) in five-grade scale: 1 - lack of damage, 2 damage up to $20 \%, 3-21-50 \%, 4-51-100 \%$ of shoot internodes infested, 5 - death of skeletal parts of bushes and whole plants. Infestation was assessed on the basis of both the color of shoots (change from brown to grey) and the excoriose visible on crosssections of older shoots.

\section{Statistical analysis}

Results concerning the weight of the removed shoots, fruit yield, rotten fruit yield, weight of clusters and berries, and soluble solids content were analyzed statistically, using analysis of variance. The significance of the means was evaluated using Duncan's test at the $5 \%$ level.

\section{RESULTS}

There were no substantial differences in the weight of fresh herbaceous shoots of the cultivar 'Solaris', removed in the years 2009-2015 between the control (non-fertilized) and the other treatments (Table 1). The highest weight of removed shoots was that of NPK + AMF followed by NPK + BF-Ecomix; however, the lowest weight of removed shoots was that of Bioilsa treatment. On the bushes of the cultivar 'Regent', which grew weaker than 'Solaris', the weight of herbaceous shoots removed from the control bushes was only significantly smaller than the weight of shoots removed from the bushes fertilized with NPK + Bioilsa. There were no substantial differences in the weights of the removed ligneous shoots among all assessed treatments performed on both cultivars.

Fruit of the cultivar 'Solaris' were harvested in mid-September, and the fruit of the cultivar 'Regent', one week later. The use of fertilizers or biostimulants did not affect in any way the time of ripening of the fruit of the two cultivars. There were no significant differences in the yield of both cultivars within single years. The only exceptions in the years mentioned were the higher marketable yield of 'Solaris' treated with Bioilsa in 2014 and 'Regent' treated with NPK + manure in 2014 and 2015. There were no significant differences found in the sum of the marketable yields in the years 2009-2015 between the untreated control and other combinations, either in the case of the cultivar 'Solaris' (Table 2) or 'Regent' (Table 3).

In 2011, the yield was low due to damage to the grapevine caused by spring frosts, and the bushes of the cultivar 'Solaris' produced significantly poorer yield on the control vines than on the vines fertilized with NPK (Table 2).

Table 1. Vine growth - cumulative weight of fresh removable shoots of 'Solaris' and 'Regent' grapevine (kg/vine), Skierniewice, 2009-2015

\begin{tabular}{lcccc}
\hline \multirow{2}{*}{ Treatment } & \multicolumn{2}{c}{ 'Solaris' } & \multicolumn{2}{c}{ 'Regent' } \\
\cline { 2 - 5 } & Herbaceous shoots & Mature shoots & Herbaceous shoots & Mature shoots \\
\hline Control & $14.9 \mathrm{abc} \pm 2.23$ & $5.71 \mathrm{a} \pm 0.43$ & $4.36 \mathrm{a} \pm 1.59$ & $2.37 \mathrm{a} \pm 0.69$ \\
NPK (mineral fertilizers) & $17.0 \mathrm{abc} \pm 1.58$ & $6.61 \mathrm{a} \pm 0.48$ & $6.89 \mathrm{ab} \pm 1.79$ & $3.41 \mathrm{a} \pm 1.02$ \\
AMF & $14.5 \mathrm{ab} \pm 2.04$ & $5.65 \mathrm{a} \pm 0.57$ & $5.26 \mathrm{ab} \pm 0.92$ & $2.88 \mathrm{a} \pm 0.21$ \\
NPK + AMF & $20.0 \mathrm{c} \pm 2.17$ & $6.43 \mathrm{a} \pm 0.66$ & $5.22 \mathrm{ab} \pm 1.87$ & $2.83 \mathrm{a} \pm 0.65$ \\
Manure & $15.9 \mathrm{abc} \pm 1.97$ & $5.69 \mathrm{a} \pm 0.21$ & $5.55 \mathrm{ab} \pm 1.83$ & $3.15 \mathrm{a} \pm 0.70$ \\
NPK + manure & $17.7 \mathrm{abc} \pm 1.92$ & $6.06 \mathrm{a} \pm 0.67$ & $6.79 \mathrm{ab} \pm 1.03$ & $3.57 \mathrm{a} \pm 0.52$ \\
Bioilsa & $12.6 \mathrm{a} \pm 2.09$ & $5.23 \mathrm{a} \pm 0.60$ & $5.41 \mathrm{ab} \pm 1.15$ & $3.13 \mathrm{a} \pm 0.48$ \\
NPK + Bioilsa & $18.6 \mathrm{bc} \pm 2.24$ & $6.32 \mathrm{a} \pm 0.58$ & $8.06 \mathrm{~b} \pm 1.86$ & $3.41 \mathrm{a} \pm 0.70$ \\
BF-Ecomix & $16.5 \mathrm{abc} \pm 1.80$ & $6.08 \mathrm{a} \pm 0.49$ & $6.43 \mathrm{ab} \pm 1.13$ & $3.20 \mathrm{a} \pm 0.60$ \\
NPK + BF-Ecomix & $19.5 \mathrm{bc} \pm 2.24$ & $6.32 \mathrm{a} \pm 0.55$ & $7.04 \mathrm{ab} \pm 1.02$ & $3.49 \mathrm{a} \pm 0.49$ \\
Ausma & $14.4 \mathrm{ab} \pm 2.16$ & $6.13 \mathrm{a} \pm 0.44$ & $5.40 \mathrm{ab} \pm 0.53$ & $2.94 \mathrm{a} \pm 0.54$ \\
NPK + Ausma & $17.6 \mathrm{abc} \pm 2.17$ & $6.42 \mathrm{a} \pm 0.63$ & $6.40 \mathrm{ab} \pm 1.75$ & $3.14 \mathrm{a} \pm 0.68$ \\
\hline
\end{tabular}

Explanation. Means in column marked by the same letter do not differ significantly at the $\mathrm{p}=0.05$ according to Duncan test, means $\pm \mathrm{SD}(\mathrm{n}=4)$. The averages were compared separately for each cultivar. 


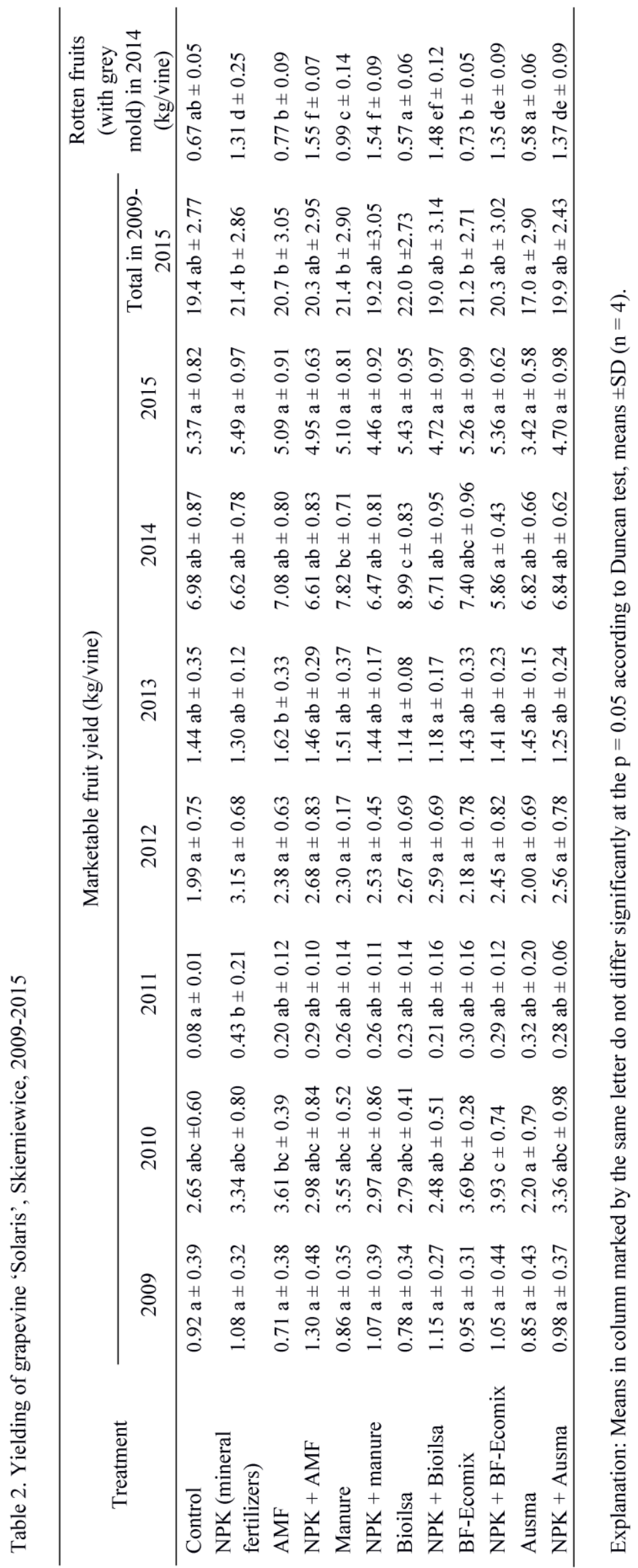




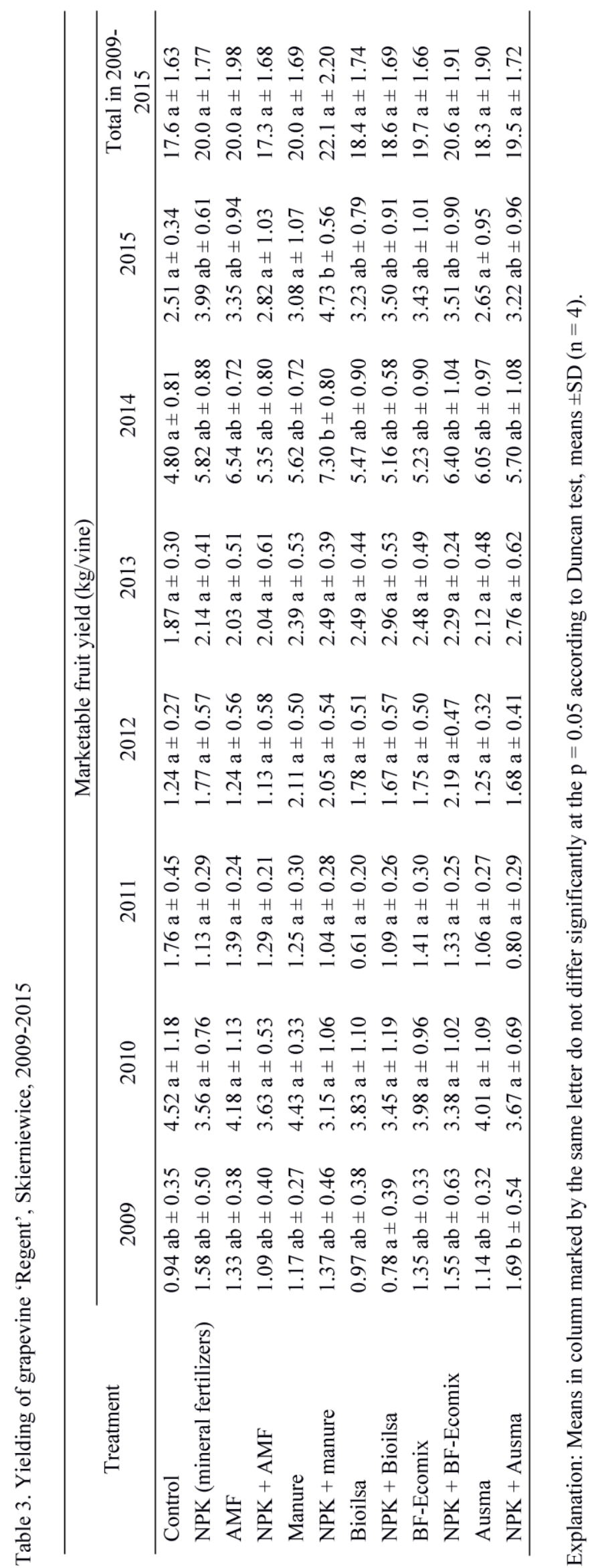




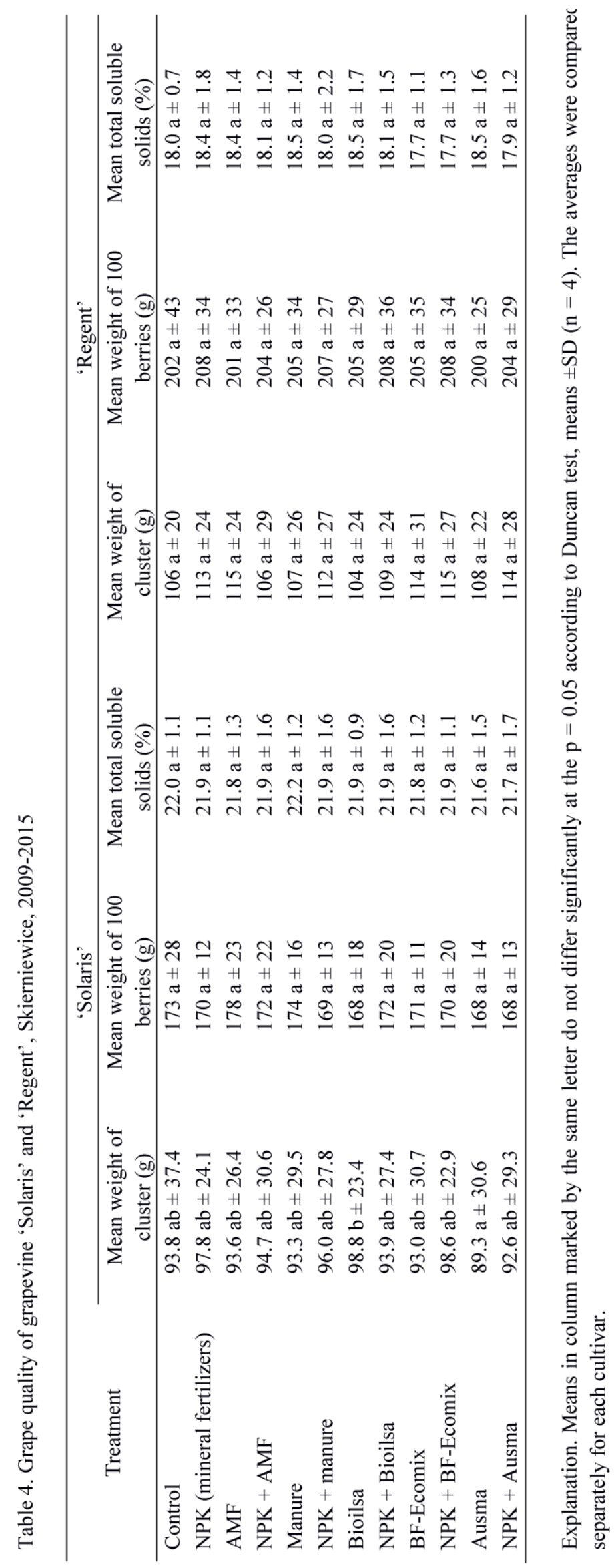


The use of fertilizers or biostimulants had no substantial influence on the mean weight of berries, mean weight of clusters, and extract content in the fruit of both cultivars in comparison to the untreated control (Table 4).

In the years 2009-2015, there were no differences observed in the two cultivars between the assessed treatments as to the degree of infestation with downy mildew (healthiness of bushes of both cultivars assessed at 1.2), powdery mildew ('Solaris' 1.6; 'Regent' - 1.4). and excoriose ('Solaris' - 1.7; 'Regent' - 2.9). No differences were observed between treatments as to the degree of infestation with grey mold of the fruits of 'Regent' in the years 20092015 (1.1) and 'Solaris' in the years 2009-2013 and 2015 (1.9). In 2014, which was characterized by high air humidity from May to September (81-86\%), the infestation of fruits of cultivar 'Solaris' fertilized with NPK (NPK only or in combination with other fertilizers and biostimulants) was higher (4 on a scale of 6) than in the fields where the NPK was not used, including the control (3 on a scale of 6). In 2014, the weight of rotten fruits of cultivar 'Solaris' from plants fertilized with NPK, NPK + AMF, NPK + manure, manure, NPK + Bioilsa, NPK + BF-Ecomix, NPK + Ausma, was considerably higher than from plants not fertilized with NPK (Table 2).

\section{DISCUSSION}

Methodical research on viticulture in Poland is still in its early stages. In the study presented here, the usefulness of both fertilizers and biostimulants was assessed. Due to different mechanisms of action, the effects of fertilizers and biostimulants were compared with the untreated control and not with one another. Grapevine cultivation in Poland takes place in conditions described as "cool climate". These conditions are strikingly different from those existing in traditional areas of cultivation of this species. This situation creates the need for specific recommendations concerning cultivars selection, fertilization and verification of results obtained in other natural conditions. Due to the nature of "cool climate", it is worth explaining the parameter which served as an illustration of the vegetative growth of the plants tested in this research. Low winter temperature and excoriose in Polish conditions cause withering of trunks whose diameter is sometimes used as an indicator of the growing rate of the plants. The weight of removed fresh herbaceous and ligneous shoots was chosen as the optimal parameter of bush growth; it also included growth of side shoots and regular summer pruning. After pruning the bushes to the same size in summer, as expected, there were no substantial differences in the weight of ligneous shoots removed during winter pruning, either in the vigorous cultivar 'Solaris' or the moderate growth rate cultivar 'Regent'.

The effects of application of fertilizers and biostimulants depend largely on the growth condition and genotype. Generally, the cultivars evaluated here react in a similar manner to mineral fertilization with NPK. Fertilization and the use of biostimulants did not increase the total weight of herbaceous and mature shoots removed from the vines of the studied cultivars in comparison with the untreated control vines, although using NPK + AMF, NPK + Bioilsa and NPK + BF-Ecomix caused an increase in the weight of herbaceous shoots, and Bioilsa decreased it. The application of NPK + Bioilsa caused a significant increase in the weight of herbaceous shoots removed from the bushes of the 'Regent'. Improvement in growth of the cultivar 'Regent' did not result in higher yield, which is a confirmation of Popescu and Popescu (2014) reports that indicated that better vegetative growth of the bushes of the cultivar 'Feteasca Alba' has no influence on their fertility.

Fertilizers and biostimulants applied here did not cause any substantial increase in the cumulative yield in the years 2009-2015 of the two cultivars in comparison to the untreated control. Some increases were observed in some years of the study after treatment with Bioilsa, NPK + manure. The tested organic fertilizers and biostimulants did not affect significantly the other parameters, such as the weight of clusters and berries and total soluble solid (TSS\%) of the two tested cultivars. Our experiment did not confirm reports on the positive effects of biostimulants or organic fertilizers on yielding and fruit quality in the cultivation of grapevine by Stroe and Budescu (2013); Colapietra and Alexander (2006); Norrie and Keathley (2006); Kok et al. (2010); Mohamed et al. (2013) obtained in experiments with other stimulators 
and cultivars. Ausma used here as foliar treatment on both tested cultivars had no effect on yielding and weight of fruit. Similar results were achieved by SasPaszt et al. (2008), who used Ausma on the bushes of blackcurrant, cultivars 'Tiben' and 'Tisel'.

Also, our results did not confirm the reports of Aziz et al. (2003); Žežlina et al. (2010); Le Mire et al. (2016) on the reduced sensitivity of grapevine to fungal diseases after the application of various biostimulants. Also, no analogies were found, with the results showing that the use of Bioilsa and Ausma reduces the sensitivity of tomato to Phytophthora infestans (Schulte-Geldermann 2008; Sharma et al. 2012). Mineral fertilization with NPK in 2014 in the conditions of high air humidity confirmedly caused intense rotting of fruits of the cultivar 'Solaris' caused by Botrytis cinerea, and the loss in yield was substantially more profound than on control fields (with no fertilization) or after application of organic fertilizers or biostimulants.

Obtained results confirm a general opinion that the effect of biostimulants and organic fertilizers on growth and yielding may be varied, unpredictable, limited only to some features and dependent on the crop cultivar or growing conditions. Conifer needle extract (Ausma) did not influence plant growth; it even reduced the number of rhizomes of the strawberry cultivar 'Zefyr' but increased the leaf growth and the number of rhizomes of the cultivar 'Kokinskaya Pozdnaya' (Laugale et al. 2006). The effect of nitrophenols (Atonic, Asahi SL) on the quality and chemical composition was ambiguous and differed depending on the tested parameter and the plant cultivar in cucumber (Przybysz et al. 2014) and eggplant fruit (Majkowska-Gadomska \& Wierzbicka 2013). Ascophyllumnodosum extract (Goëmar BM 86) caused an increase in fruit weight in three out of five tested raspberry cultivars, and its effect on dry matter, extract content, simple sugar content, organic acid and anthocyanins was insignificant and depended largely on growing season and cultivar (Krok \& Wieniarska 2008). The effect of nitrophenols (Asahi SL) on growth and yielding of three strawberry cultivars varied and differed depending on the cultivar (Sas-Paszt et al. 2008). Ecklonia maxima extract (Kelpak) and Ascophyllumnodosum extract (Goëmar BM 86) applied on strawberry cultivars
'Elkat' and 'Salut' increased the yield produced of the cultivar 'Salut' but reduced the fruit firmness in both cultivars (Masny et al. 2004). Ascophyllumnodosum extract (Goëmar BM 86) + nitrophenols (Asahi SL) had a positive effect on the yield produced by chokeberry only during dry summers, and had no effect on plant growth and quality of fruit (Krawiec 2008).

Biostimulants can be applied in different ways. One method involves using them together with synthetic fertilizers and pesticides in order to reduce the use of the latter two (Le Mire et al. 2016). Such approach works in growing fruits where the use of mineral fertilizers with the addition of seaweed extract in the "N Pro technology and seactiv complex" technology increases the fertility, length of one-year shoots and the surface area of apple leaves of the cultivar 'Šampion' (Kapłan et al. 2013). The results of our study showed no significant influence of mixture of biostimulants and organic fertilizers with mineral fertilizers on improving the growth and yielding of plants.

Another method holds that biostimulants such as mycorrhizal agents are especially attractive in reduced input cultivation systems in long-term cultivation of fruit plants, including grapevine, where the mineral fertilizing does not have as strong an effect as in annual crop growing (Balestrini et al. 2010). Taking into account the results of our study, this method seems more interesting since it allows adjustment of the cultivation to the certified organic production.

\section{CONCLUSIONS}

1. The study showed no definite positive effect of the organic fertilizers and biostimulants on growth, yielding and healthiness of the grapevine cultivars 'Solaris' and 'Regent'.

2. Bushes of cvs 'Solaris' and 'Regent', grafted on the $\mathrm{SO} 4$ rootstock and planted in soil rich in mineral compounds, grew well and produced good yield despite lack of mineral fertilization for many years.

3. The annual use of AMF and organic fertilizers Bioilsa and BF-Ecomix, which are recommended in organic farming, resulted in yield at the same level as mineral fertilizing with NPK. 
4. In the conditions of high air humidity during vegetation, on fields fertilized with NPK, an intensive rotting of fruit of the cultivar 'Solaris' was observed, which was caused by Botrytis cinerea.

5. Good tolerance to fungal diseases and lack of mineral fertilization showed that the grapevine cultivars 'Solaris' and 'Regent' may be recommended for organic production.

\section{Acknowledgments}

This study was supported by the Ministry of Science and Higher Education of Poland as the part of statutory activities of Research Institute of Horticulture, within the project "The effect of biostimulators of soil biosphere on root system development, plant growth and yielding of grapevines", project no. 3.2.2.

\section{REFERENCES}

Aziz A., Poinssot B., Daire X., Adrian M., Bézier A., Lambert B., Joubert J.M., Pugin A. 2003. Laminarin elicits defense responses in grapevine and induces protection against Botrytis cinerea and Plasmopara viticola. Molecular Plant-Microbe Interactions 16(12): 1118-1128. DOI: 10.1094/MPMI.2003.16.12.1118.

Balestrini R., Magurno F., Walker C., Lumini E., Bianciotto V. 2010. Cohorts of arbuscular mycorrhizal fungi (AMF) in Vitis vinifera, a typical Mediterranean fruit crop. Environmental Microbiology Reports 2(4): 594-604. DOI: 10.1111/j.1758-2229.2010.00160.x.

Baumgartner K., Smith R.F., Bettiga L. 2005. Weed control and cover crop management affect mycorrhizal colonization of grapevine roots and arbuscular mycorrhizal fungal spore populations in a California vineyard. Mycorrhiza 15(2): 111-119. DOI: 10.1007/s00572-004-0309-2.

Biricolti S., Ferrini F., Rinaldelli E., Tamantini I., Vignozzi N. 1997. VAM fungi and soil lime content influence rootstock growth and nutrient content. American Journal of Enology and Viticulture 48(1): 93-99.

Colapietra M., Alexander A. 2006. Effect of foliar fertilization on yield and quality of table grapes. Acta Horticulturae 721: 213-218. DOI: 10.17660/ActaHortic.2006.721.28.

Donkó Á., Zanathy G., Èros-Honti Z., Villangó S., Bisztray G.D. 2014. Changes of mycorrhizal colonization along moist gradient in a vineyard of Eger (Hungary). Acta Universitatis Sapientiae, Agriculture and Environment 6(1): 13-23. DOI: 10.2478/ausae-2014-0008.
El-Sabagh A.S., El-Morsy F.M., Farag A.R. 2011a. Effect of biofertilizers as a partial substitute for nitrogen fertilizer on vegetative growth, yield, fruit quality and leaf mineral content of two seedless grape cultivars. I: Vegetative growth and yield. Journal of Horticultural Science \& Ornamental Plants 3(2): 166-175.

El-Sabagh A.S., El-Morsy F.M., Farag A.R. 2011b. Effect of biofertilizers as a partial substitute for nitrogen fertilizer on vegetative growth, yield, fruit quality and leaf mineral content of two seedless grape cultivars. II: Fruit quality and leaf mineral content. Journal of Horticultural Science \& Ornamental Plants 3(2): 176-187.

Górnik K., Grzesik M., Mika A. 2007. Improvement of grapevines rooting and growth of plants under stress conditions by Asahi SL. Folia Horticulturae 19(2): 57-67.

Górnik K., Grzesik M., Romanowska-Duda B. 2008. The effect of Chitosan on rooting of grapevine cuttings and on subsequent plant growth under drought and temperature stress. Journal of Fruit and Ornamental Plant Research 16: 333-343.

Hawkins H.J., Johansen A., George E. 2000. Uptake and transport of organic and inorganic nitrogen by arbuscular mycorrhizal fungi. Plant and Soil 226(2): 275285. DOI: 10.1023/A:1026500810385.

Hodge A., Campbell C.D., Fitter A.H. 2001. An arbuscular mycorrhizal fungus accelerates decomposition and acquires nitrogen directly from organic material. Nature 413: 297-299. DOI: 10.1038/35095041.

Kapłan M., Baryła P., Krawiec M., Kiczorowski P. 2013. Effect of $\mathrm{N}$ pro technology and seactiv complex on growth, yield quantity and quality of 'Szampion' apple trees. Acta Scientiarum Polonorum. Hortorum Cultus 12(6): 45-56.

Kok D., Bal E., Celik S., Ozer C., Karauz A. 2010. The influences of different seaweed doses on table quality characteristics of cv. Trakya Ilkeren (Vitis vinifera L.). Bulgarian Journal of Agricultural Science 16(4): 429-435.

Krawiec P. 2008. Effects of biostimulators on growth, cropping and fruit quality of chokeberry. In: A. Sadowski (ed.). Monographs Series: Biostimulators in Modern Agriculture, Fruit Crops. Wieś Jutra, Warszawa, p.: 42-48.

Krok K., Wieniarska J. 2008. Effect of Goëmar BM 86 application on development and quality of primocane raspberry fruits. In: A. Sadowski (ed.). Monographs Series: Biostimulators in Modern Agriculture, Fruit Crops. Wieś Jutra, Warszawa, p. 49-59.

Laugale V., Lepse L., Daugavietis M. 2006. Using growth stimulator Ausma in strawberry plant production. Latvian Journal of Agronomy 9: 64-68. 
Le Mire G., Nguyen M.L., Fassotte B., du Jardin P., Verheggen F., Delaplace P., Jijakli M.H. 2016. Implementing plant biostimulants and biocontrol strategies in the agroecological management of cultivated ecosystems. A review. Biotechnologie, Agronomie, Société et Environnement 20(S1): 299-313.

Li H.Y., Yang G.D., Shu H.R., Yang Y.T., Ye B.X., Nishida I., Zheng C.C. 2006. Colonization by the arbuscular mycorrhizal fungus Glomus versiforme induces a defense response against the root-knot nematode Meloidogyne incognita in the grapevine (Vitis amurensis Rupr.), which includes transcriptional activation of the class III chitinase gene VCH3. Plant and Cell Physiology 47(1): 154-163. DOI: 10.1093/pcp/pci231.

Linderman R.G., Davis E.A. 2001. Comparative response of selected grapevine rootstocks and cultivars to inoculation with different mycorrhizal fungi. American Society for Enology and Viticulture 52(1): 8-11.

Lisek J. 2010. Yielding and healthiness of selected grape cultivars for processing in Central Poland. Journal of Fruit and Ornamental Plant Research 18(2): 265-272.

Lott H., Pfaff F., Prior B. 2010. Taschenbuch der Rebsorten. 13 Auflage. Fachverlag Dr. Fraund GmbH, Mainz, 385 p. [in German]

Majkowska-Gadomska J., Wierzbicka B. 2013. Effect of the biostymulator Asahi SL on the mineral content of eggplants (Solanum melongenum L.) grown in an unheated plastic tunnel. Journal of Elementology 18(2): 269-276. DOI: 10.5601/jelem.2013.18.2.06.

Masny A., Basak A., Żurawicz E. 2004. Effects of foliar application of Kelpak SL and Goëmar BM $86^{\circledR}$ preparation on yield and fruit quality in two strawberry cultivars. Journal of Fruit and Ornamental Plant Research 12: 23-27.

Mäder P., Vierheilig H., Streitwolf-Engel R., Boller T., Frey B., Christie P., Wiemken A. 2000. Transport of ${ }^{15} \mathrm{~N}$ from a soil compartment separated by a polytetrafluoroethylene membrane to plant roots via the hyphae of arbuscular mycorrhizal fungi. New Phytologist 146(1): $\quad 155-161$. DOI: $10.1046 /$ j.14698137.2000.00615.x.

Mohamed A.R.M.A., Abdel-Aziz F.H., Mohamed M.A., Gobara A. 2013. Effect on foliar application of Sida Compound fertilizer on growth, yield, and fruit chemical composition of 'Early Superior' grapevine. Journal of Horticultural Research. 21(2): 53-57. DOI: 10.2478/johr-2013-0021.

Nicolás E., Maestre-Valero J.F., Alarcón J.J., Pedrero F., Vincente-Sánchez J., Bernabé A., et al. 2015. Effectiveness and persistence of arbuscular mycorrhizal fungi on the physiology, nutrient uptake and yield of
Crimson seedless grapevine. The Journal of Agricultural Science 153(6): 1084-1096. DOI: 10.1017/S002185961400080X.

Nikolaou N., Angelopoulos K., Karagiannidis N. 2003. Effects of drought stress on mycorrhizal and non-mycorrhizal Cabernet Sauvignon grapevine, grafted onto various rootstocks. Experimental Agriculture 39(3): 241-252. DOI: 10.1017/S001447970300125X.

Norrie J., Keathley J.P. 2006. Benefits of Ascophyllum nodosum marine-plant extract applications to 'Thompson seedless' grape production. Acta Horticulturae 727: 243-248. DOI: $10.17660 /$ ActaHortic.2006.727.27.

OIV: International Organisation of Vine and Wine, Statistical report on world vitiviniculture. 2013. www.oiv.com.

Ozdemir G., Akpinar C., Sabir A., Bilir H., Tangolar S., Ortas I. 2010. Effect of inoculation with mycorrhizal fungi on growth and nutrient uptake of grapevine genotypes (Vitis spp.). European Journal of Horticultural Science 75(3): 103-110

Patrick A.E., Smith R., Keck K., Berry A.M. 2004. Grapevine uptake of ${ }^{15} \mathrm{~N}$-labeled nitrogen derived from a winter-annual leguminous cover-crop mix. American Journal of Enology and Viticulture 55(2): 187-190.

Popescu G.C., Popescu M. 2014. Effect of the brown alga Ascophyllum nodosum as biofertilizer on vegetative growth in grapevine (Vitis vinifera L.). Current Trends Natural Sciences 3(6): 61-67.

Przybysz A., Gawrońska H., Gajc-Wolska J. 2014. Biological mode of action of a nitrophenolates-based biostimulant: case study. Frontiers in Plant Science 5: 713. DOI: 10.3389/fpls.2014.00713.

Romanazzi G., D’Ascenzo D., Murolo S. 2009. Field treatment with resistance inducers for the control of grapevine Bois noir. Journal of Plant Pathology 91(3): 677-682.

Sas-Paszt L., Żurawicz E., Masny A., Filipczak J., Pluta S., Lewandowski M., Basak A. 2008. The use of biostimulators in small fruit growing. In: A. Sadowski (ed.). Monographs Series, Biostimulators in Modern Agriculture, Fruit Crops. Wieś Jutra, Warszawa, pp. 76-90.

Sharma K., Bruns C., Butz A.F., Finckh M.R. 2012. Effects of fertilizers and plant strengtheners on the susceptibility of tomatoes to single and mixed isolates of Phytophthora infestans. European Journal of Plant Pathology 133(3): 739-751. DOI: 10.1007/s10658-0129954-z.

Schulte-Geldermann E. 2008. Management approaches in organic potato and tomato production: Interactive 
impacts of agronomical measures on plant nutrition, plant health and yield. $\mathrm{PhD}$ thesis, University of Kassel, Germany, 123 p. [in German]

Schreiner R.P. 2003. Mycorrhizal colonization of grapevine rootstocks under field conditions. American Journal of Enology and Viticulture 54(3): 143-149.

Schreiner R.P. 2005. Mycorrhizas and mineral acquisition in grapevines. In: D.R. Smart, L.P. Christensen (eds.). Proceedings of the soil environment and vine mineral nutrition symposium. American Society for Enology and Viticulture, p. 49-60.

Schreiner R.P. 2007. Effects of native and nonnative arbuscular mycorrhizal fungi on growth and nutrient uptake of 'Pinot noir' (Vitis vinifera L.) in two soils with contrasting levels of phosphorus. Applied Soil Ecology 36(2-3): 205-215. DOI: 10.1016/j.apsoil.2007.03.002.

Schreiner R.P., Linderman R.G. 2005. Mycorrhizal colonization in dryland vineyards of the Willamette Valley, Oregon. Small Fruits Review 4(3): 41-55. DOI: 10.1300/J301v04n03_04.

Schreiner R.P., Mihara K.L. 2009. The diversity of arbuscular mycorrhizal fungi amplified from grapevine roots (Vitis vinifera L.) in Oregon vineyards is seasonally stable and influenced by soil and vine age. Mycologia 101(5): 599-611. DOI: 10.3852/08-169.
Schreiner R.P., Tarara J.M., Smithyman R.P. 2007. Deficit irrigation promotes arbuscular colonization of fine roots by mycorrhizal fungi in grapevines (Vitis vinifera L.) in an arid climate. Mycorrhiza 17(7): 551-562. DOI: 10.1007/s00572-007-0128-3.

Stroe M., Budescu C. 2013. Comparative study regarding the influence of biostimulators on the qualitative and quantitative potential of Cabernet Sauvignon. Scientific Papers, Series B, Horticulture LVII: 115-120.

Theocharis A., Hand P., Pole J., Cevik V., Fisarakis I., Henderson J. 2010. Study of genetic diversity among inter-intraspecific hybrids and original grapevine varieties using AFLP molecular markers. Australian Journal of Crop Science 4(1): 1-8.

Turan M., Köse C. 2004. Seaweed extracts improve copper uptake of grapevine. Acta Agriculturae Scandinavica, Section B - Soil \& Plant Science 54(4): 213-220. DOI: 10.1080/09064710410030311.

Vitis International Variety Catalogue. www.vivc.de (accessed 09.02.2016).

Žežlina I., Škvarč A., Rusjan D., Trdan S. 2010. The efficacy of different spraying programs against two fungal pathogens in organic grape production. Journal of Plant Diseases and Protection 117(5): 220-225. DOI: 10.1007/BF03356364. 